\title{
Change and Continuity in Amish Wedding Dates in the Holmes County, Ohio, Settlement
}

\author{
Henry Troyer \\ Retired Professor \\ Independent Research Specialist \\ Springfield, Missouri \\ hetroyer625@gmail.com
}

\begin{abstract}
In the past century, the Amish of Holmes County, Ohio, have experienced an enormous population increase (from continued high fertility) and a serious decline in farming (from land shortage). We wondered if their traditional pattern of weddings might also have changed. We showed that whereas weddings used to occur almost exclusively in winter months, with a peak in December, they now occur in spring, summer, and early fall, but hardly ever in December. Two developments may be responsible. Refrigeration and other technologies for preserving food are now allowed in many Amish churches, making it possible to safely preserve wedding foods in warm weather. December weddings used to interfere minimally with the busy farming season, but now with farming in serious decline, that is no longer an issue. The traditional practice of having weddings on Thursdays and to a lesser extent on Tuesdays remains almost unchanged for the past several centuries. Much work is involved in wedding preparation and in cleanup after the wedding. For that reason, it is desirable to avoid holding weddings on Saturdays and Mondays, since much Sunday work would be required.
\end{abstract}

Submitted October 2, 2020; accepted December 8, 2020; published March 24, 2021

https://doi.org/10.18061/jpac.v1i2.7948

Keywords: tradition, weddings, farming, Amish

\section{Introduction}

This investigation took place in the Holmes County, Ohio, Amish settlement, one of the two largest Amish settlements today. This settlement encompasses most of Holmes County, significant portions of Wayne County, Tuscarawas County, and Coshocton County, and a corner of Stark County. The settlement contains seven different Amish groups, which can all be placed along a conservative-progressive continuum. The smallest group consists of one district and the largest consists of 184 districts.

The Amish have historically been an agricultural people, a characteristic rooted deep in their historic European experience. They are a family-oriented, rural people with large families, and farming for the Amish is a family affair. The Amish do mixed farming (meaning some dairying, and some grain and forage farming) on farms ranging from about 100 to 160 acres. Amish are rarely engaged in monocropping. They are known for hard work and large families, characteristics compatible with minimally mechanized, labor-intensive family farms. By and large, they have been successful in their American experience as agricultural people, but in the past half century, 
they have met significant challenges to their predilection for farming (Kraybill, Johnson-Weiner, and Nolt 2013).

The Amish community of Holmes County, with its large families and rapid community expansion, has experienced an insufficient supply of farmland to continue its emphasis on farming. That means that young would-be farmers are forced to either relocate to a newer, smaller community where farmland remains available and affordable or take up nonfarming occupations. Several research papers have documented the farming-to-nonfarming occupational trend among the Holmes County, Ohio, Amish community (Lowery and Noble 2000; Kreps, Donnermeyer and Kreps 1994; Troyer and Willoughby 1984), and the consequences for future Amish generations.

Traditionally, weddings are closely synced with the rhythm of a farming community, so if there is a serious shift away from farming as a livelihood, there may also be significant changes in the timing of wedding patterns. At age sixteen, Amish young people begin to run around socially with other Amish youths by attending Sunday evening singings and certain Saturday evening social functions. Among the Amish, this is called rumspringa. This is also the period in the young people's lives when dating begins. Dating at first is a somewhat casual affair, but later it becomes more serious, with the intent of finding a life partner. When the boy and girl feel that they are compatible, they will "go steady" and further test their commitment to each other. They may soon decide to get married or (rarely) dissolve their relationship. Once the commitment is made to get married, the couple will make their intentions known to the ministers of the church. In the past, their decision to get married was kept strictly secret within the small circle of families involved. Outside that circle, there was often copious gossip about when they will get married (Kraybill, Johnson-Weiner, and Nolt 2013).

Then one Sunday in church, the bishop will get up and announce the couple's decision to the congregation - this is called aus ruffa (to call out; announce) — which often gives rise to surprise and even more gossip. The wedding typically follows in a week and a half. However, in recent years, significant changes have occurred in this premarital dynamic. Knowledge of a couple's intention to get married today increasingly becomes known for months or even a year ahead of the event.

At around the time of the wedding, the young couple to be married make an abrupt visible change in their social status. At social events the young man leaves the boys and joins the men, and the young woman joins the women. That is also when the young man begins growing a beard, a requirement for married Amish men. The community looks on the couple's transition with complete approval and acceptance.

Traditionally, most weddings take place on Thursdays. Seldom do weddings take place on Saturdays or even more rarely on any other day of the week. ${ }^{1}$ In the distant past, weddings were sometimes incorporated into the regular Sunday worship service, but that no longer seems to occur. No one seems to know exactly why Thursday is the dominant day for weddings but a compelling rationale has been constructed. The day before a wedding is spent preparing a large amount of

\footnotetext{
${ }^{1}$ The notable exception is that nowadays the New Order Amish hold all their weddings on Saturdays.
} 
food for the guests. The operation starts early in the morning and involves not only the family of the bride but also certain neighbors and relatives who are recruited to help. A major all-day cleanup operation takes place the day after the wedding. It is obvious then that Mondays and Saturdays would not make good wedding days, because either the food preparation day before or the cleanup day after would fall on a Sunday, and the Amish are quite serious about keeping Sunday as the Lord's Day (Scott 1998). It is not clear why weddings are not held on Wednesdays and Fridays, but perhaps it is simply due to tradition.

In the past, weddings nearly always occurred during the winter months, with the peak in December. One reason for winter weddings is that it is the season when weddings would best fit into a farming community dynamic. Farmwork is to a great extent seasonal: planting in the spring, harvesting in the fall, and hay-making, farm maintenance, and facility upgrading in the summer. Social events, including weddings, occurred predominantly during winter months, when farmwork is light. A second reason for winter weddings is that wedding food is more easily preserved in cold weather.

The actual wedding ceremony takes place at a neighbor's home, freeing the bride's home for the wedding dinner preparation and the activities that follow. The wedding ceremony consists of a few hymns and prayers and then a sermon that is appropriate for a wedding. Following the sermon, the wedding couple stands in front of the minister and exchanges vows. Another hymn is sung and the ceremony is over. The wedding party is escorted out to several waiting horse-andbuggy rigs that will take them back to the bride's home, and all the wedding guests follow. An elaborate wedding dinner is served. The focal point of the wedding dinner is das eck (the corner). The wedding party is seated around one corner of the living room or other locality where the tables are arranged for the fellowship meal. Also in the corner is an elaborate wedding cake. An empty table off to the side is for wedding gifts. After the dinner, the men and women sit around and visit and sing hymns, and the young people sometimes play games. An evening meal is served and evening activities begin. The emphasis in the evening is on the young unmarried people who sit around and play games. At about 10 o'clock, preparations are made for des halb nacht stuck, "the midnight snack." The unmarried young people are paired to eat together as couples. By midnight, the guests have cleared out. At an Amish wedding, there are no photographs, no wedding rings, and no elaborate gowns. No rice is thrown, no garter is tossed, no alcohol beverages are served, and no dancing takes place (Scott 1998).

\section{Objectives}

The goal of this research is to identify the changes that accompany the Amish transition from mostly farming to largely nonfarming occupations. There are two objectives: to determine changes in the pattern of months that weddings are held and to detect any changes in the pattern of days of the week that weddings are held. 


\section{Data Sources}

Data from Ohio Amish Directory, Holmes County and Vicinity, 2020 were encoded into an Excel spreadsheet, except the data for smaller non-contiguous communities like Adamsville, Tiverton, McKay, Danville, Brinkhaven, Walhonding, Glenmont, West Union, Gallipolis, and Barlow. Data from Ohio Amish Directories Holmes County and Vicinity, 1996 and 1965 editions, encoded for use in previous studies, were also employed.

Data also were collected from Descendants of Barbara Hochstedler and Christian Stutzman, compiled by Harvey Hostetler and published in 1938. Data were encoded from families that met three criteria: (1) they identified themselves as Amish; (2) they lived in the Holmes County area; and (3) the mother/wife was born before 1885. At that cutoff date, all the families could be considered completed families. These data were used to create an antiquity baseline.

Personal, residential, and occupational data were encoded. The marriage dates of 1 in 10 families in each of these data sources were converted to day of the week (Sunday, Monday, Tuesday, etc.) using the calculator at the website https://calcuworld.com/calendar-calculators/day-of-the-weekcalculator/. The data were encoded for the marriage-day-of-the-week segment of the study.

\section{Data Analysis}

The data were analyzed using Excel spreadsheet formulas. Figure 1 shows the month of Amish weddings from the antiquity baseline. Figure 2 displays wedding months for four time periods in the twentieth and twenty-first centuries.

\section{Figure 1}

Amish Weddings throughout the Year for Most of the Nineteenth Century

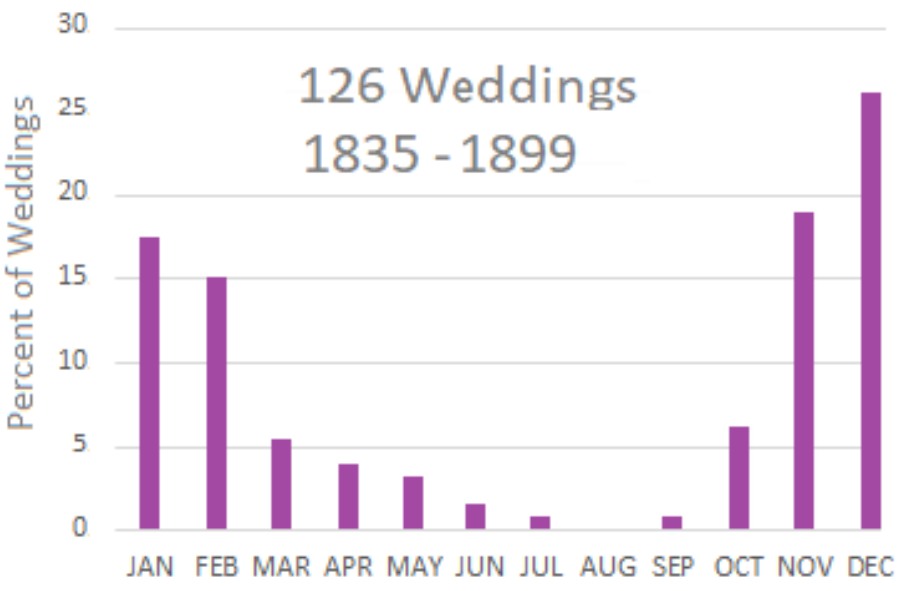


Figure 2

Amish Weddings through the Year over the Years

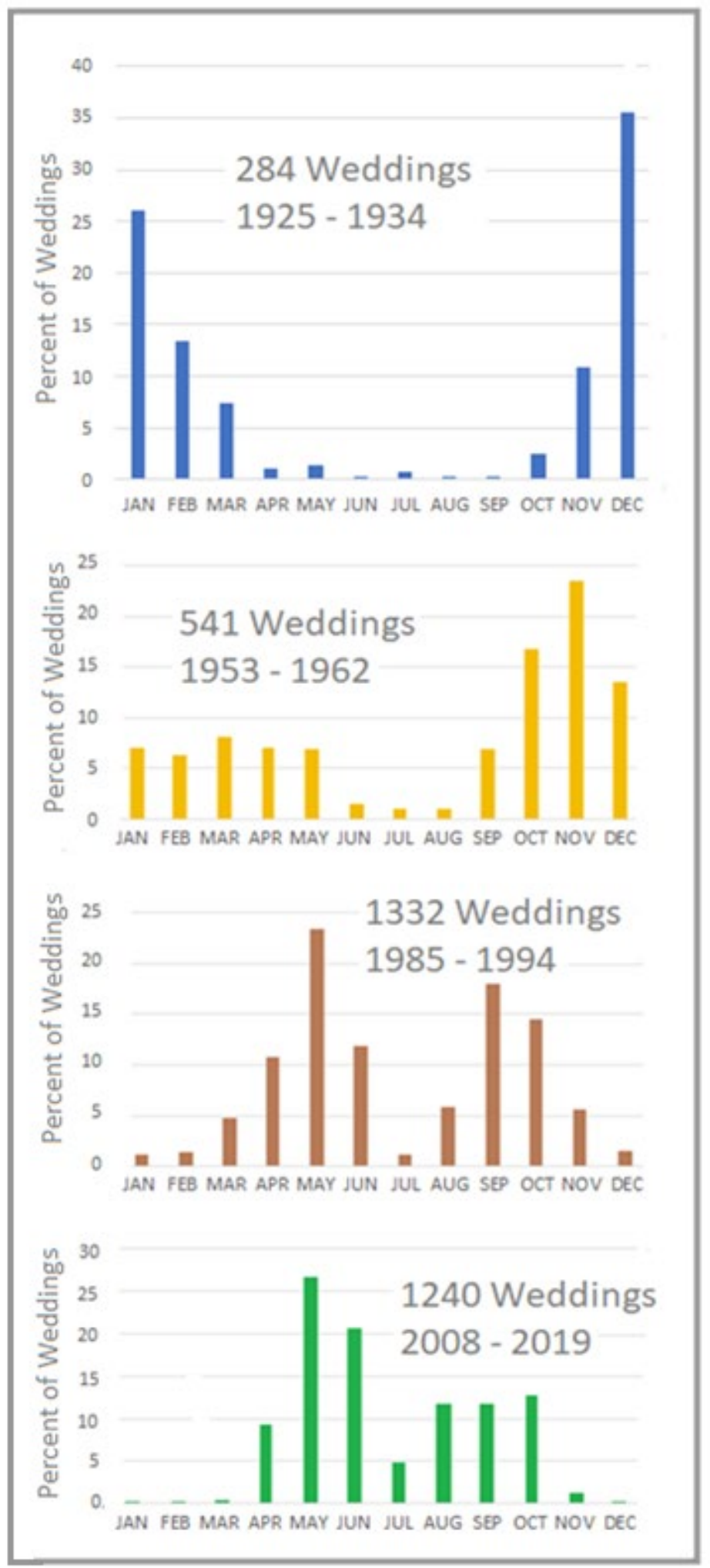


Until around 1930 (see Figure 1 and the first panel of Figure 2), the wedding season was strongly centered in December, with a significant number of weddings also occurring in November, January, and February. By around 1958 and 1990 (second and third panels of Figure 2), the weddings were spread out over the year with a mild bipolar pattern and a trough centered in July. By about 2013 (fourth panel of Figure 2), practically all the weddings occurred from April through October and practically none during the winter months. This represents a complete reversal from the pattern seen before 1925 .

Figure 3 shows, by decade, the percentage of all the weddings that occurred on Thursdays, Tuesdays, and weekend days. Over the 150 years, most of the weddings occurred on Thursdays (blue), some on Tuesdays (orange), and a few on weekends (green). For the past several centuries, most Amish weddings occurred on Thursdays, a pattern that has not changed substantially over the period of this study.

\section{Figure 3}

Amish Weddings as They Occurred throughout the Week over a Span of 150 Years

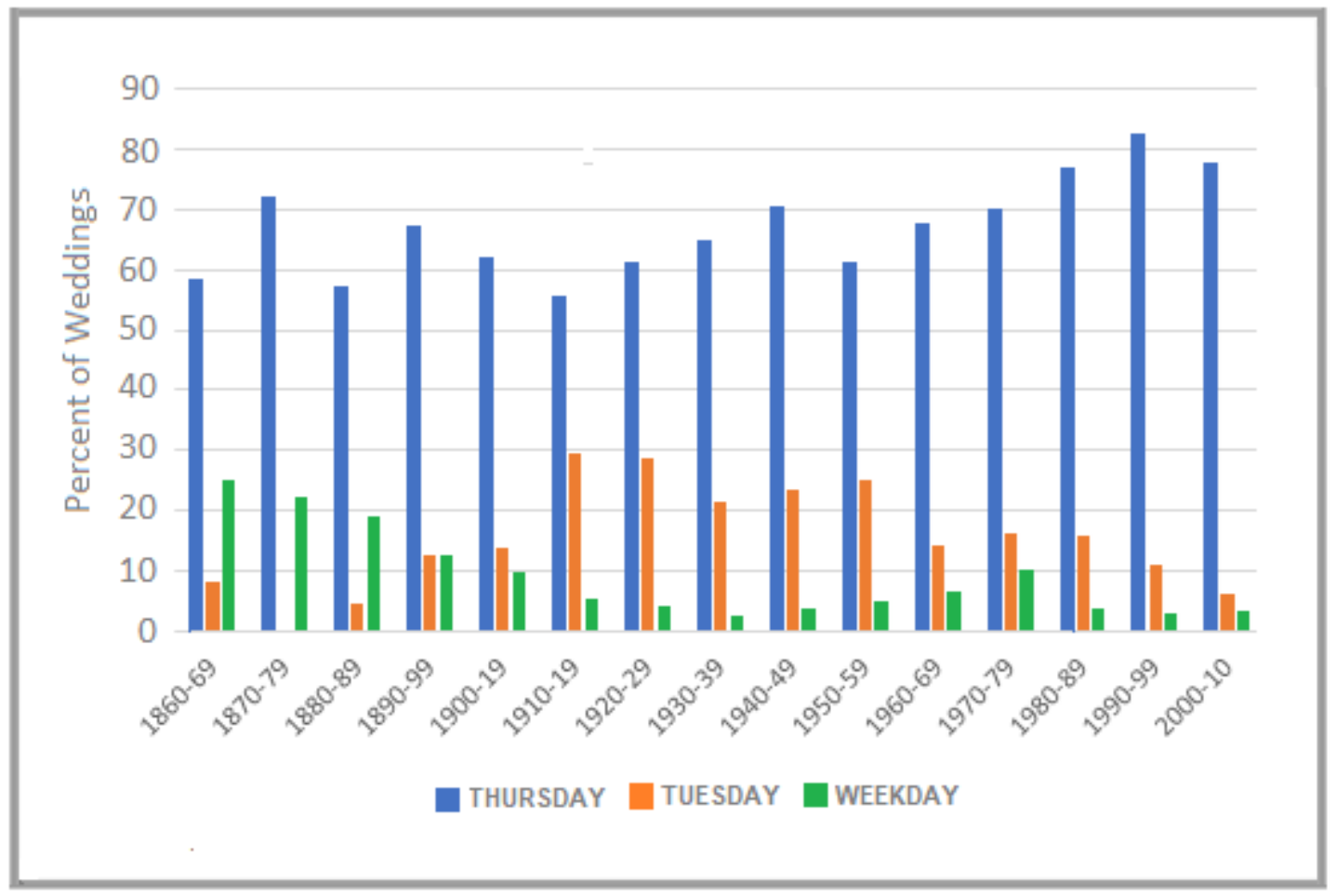

\section{Discussion}

A wedding is no doubt the most important social event in the life of most Amish people. The wedding event is packed full of cultural and traditional aspects. A wedding is a rite of passage made by the bride and groom, representing a symbolic change in their statuses within Amish society, from childhood into adulthood (Scott 1998). It is therefore fitting that the wedding is a 
large, joyous, and commemorative occasion. This is perfectly in keeping with the centrality of the home and family in Amish society (Bachman 1961).

In the present study, the goal was to examine possible changes in the month and day on which Amish weddings occur over time. To a great extent, the Amish are tradition-bound, but in other ways, the Amish are surprisingly dynamic, constantly adjusting their community standards in order to prosper economically and yet live lives faithful to their convictions as a "separate" people (Hostetler 1996). Large families, such that their population doubles roughly every 20 years (Kraybill, Johnson-Weiner, and Nolt 2013), eventually force changes upon the community. Another factor that drives change is the dwindling availability and rising price of farmland. The result is that the percentage of Amish families engaged in fulltime farming has decreased rather dramatically (Nethers 1983; Ericksen, Ericksen, and Hostetler 1980; Kreps, Donnermeyer, and Kreps 1994; Troyer and Willoughby 1984; Donnermeyer 2017). Amish men are enticed to take up nonfarming occupations such as factory and retail jobs.

In light of occupational changes among the Amish, one objective was to understand the changes that might occur in the pattern of weddings. Traditionally, weddings were held during a yearly "wedding season" centered in December, and held on Thursdays. When change is forced upon the Amish community (like farming to nonfarming), do these wedding traditions persist or do they change to accommodate altered conditions? The data show that the wedding season for the Holmes County, Ohio, Amish community underwent a very significant change over a period of perhaps 80 years, evidently in response to occupational changes (see Figure 1 and the four panels in Figure 2). There is reason to believe that the pattern seen in Panel 1 was the pattern that prevailed through the past several centuries. Hence, the Amish do indeed change to accommodate altered social conditions, which, in this case, was their concomitant shift out of agriculture and into nonagricultural jobs on the part of men.

If there was an abundance of farmland and all Amish families farmed that were inclined to do so, what percentage would farm? Such a baseline seems not to exist. The portion of Amish families who farmed in 1965 was determined to be 67 percent by one study (Troyer and Willoughby 1984) and 73 percent by another study (Kreps, Donnermeyer, and Kreps 1994). The difference, though small, is in the manner of constructing the denominator, not in counting farmers. That time frame (1965) corresponds to the second panel of Figure 2. A tabulation of the 2020 data suggests that 8.23 percent are farmers, 10.26 percent if part-time farmers are included. There is reason to believe that the trend away from farming began around 1965, although precise documentation on when this trend began is not yet available.

A strong rationale exists for the December-January wedding season in "the old days." Since there has been a dramatic occupational change from farming to nonfarming, there is no longer a seasonal lull in work during which to have weddings and other social events. Can that custom be adjusted when circumstances change? The data clearly show that the traditional wedding season was not sacrosanct but could be changed when needed. There were also other developments that facilitated warm weather weddings. Refrigeration became available by way of portable refrigerator 
units that could be rented for weddings to facilitate food preparation and storage, and in some Amish communities, owning a freezer powered by propane or some other source is now allowed by the church discipline. Amish weddings were traditionally held on weekdays, strongly favoring Thursdays. If the month could change so dramatically in less than a century, could the day of the week change as well? Our data showed that the Thursday wedding day has not changed over the past 150 years. A day's worth of work is required to prepare for a wedding, and another day is required after the wedding day for cleaning up and reestablishing a degree of normalcy. The main consideration was avoiding Sunday for either pre-wedding preparation or post-wedding clean up (Scott, 1998). Although there have been significant changes in the Amish community, those changes had no influence on changing Thursday as the predominant wedding day. Hence, the data demonstrated that the Thursday wedding day has not changed much, and mostly over the practicalities of hosting large crowds for a symbolically important rite of passage for newlywed couples.

\section{Conclusion}

The winter wedding season of the Amish, which used to peak in December, has changed dramatically over the last 80 years. The wedding season now begins in April, continues through the summer, and ends in October. Practically no weddings occur in December. This change in the wedding season occurred roughly during the same period in which there was a strong trend from farming to nonfarming (related to farmland availability), suggesting a cause-and-effect relationship, although that aspect was not explored in this article. On the other hand, Thursday as the dominant weekday for weddings has not changed in the Amish community for the past few centuries. Presumably, the Amish community has not experienced any developments that would encourage changing the Thursday wedding tradition. The Amish community makes adjustments in the life of its community when it is sensible and continues community life unchanged when that is sensible.

\section{References}

Bachman, Calvin George. 1961. The Old Order Amish of Lancaster County. Lancaster, PA: Pennsylvania German Society.

Donnermeyer, Joseph F. 2017. "The Great Agricultural Transition of Amish Society." Paper presented at the annual meeting of the Rural Sociological Society, Columbus, Ohio.

Ericksen, Eugene, Julia Ericksen, and John Hostetler. 1980. "The Cultivation of the Soil as a Moral Directive: Population Growth, Family Ties, and the Maintenance of Community among the Old Order Amish." Rural Sociology 45 (1): 49-68.

Hostetler, John A. 1993. Amish Society. 4th ed. Baltimore: Johns Hopkins University Press

Kraybill, Donald, B., Karen Johnson-Weiner, and Steven M. Nolt. 2013. The Amish. Baltimore: Johns Hopkins University Press. 
Kreps, George M., Joseph F. Donnermeyer, and Marty W. Kreps. 1994. "The Changing Occupational Structure of Amish Males.” Rural Sociology 59 (4): 708-719. https://doi.org/10.1111/j.1549-0831.1994.tb00556.x

Lowery, Sean, and Allen G. Noble. 2000. "The Changing Occupational Structure of the Amish of the Holmes County, Ohio, Settlement." Great Lakes Geographer 7 (1): 26-37.

Nethers, John. 1983. "Occupational Changes among the Old Order Amish in the Holmes County Vicinity of Ohio." Communal Societies 3 (Fall): 122-139.

Scott, Stephen. 1998. The Amish Wedding and Other Special Occasions of the Old Order Communities. Intercourse, PA: Good Books.

Troyer, Henry, and Lee Willoughby. 1984. "Changing Occupational Patterns in the Holmes County, Ohio, Amish Community." In Internal and External Perspectives on Amish and Mennonite Life 1, edited by Warner Enninger, 52-80. Essen, Germany: Unipress. 